\title{
Ekmeklik Buğday (Triticum aestivum L.) Genotiplerinde Farklı Bitki Gelișme Dönemlerinde Kuraklık Uygulamalarının Kalite Karakterlerine Etkisi
}

\author{
*irfan ÖZTÜRK¹, Kayıhan Zahit KORKUT² \\ ${ }^{1}$ Trakya Tarımsal Araștırma Enstitüsü, PK:16 Edirne \\ ${ }^{2}$ Namık Kemal Üniversitesi Ziraat Fakültesi, Tarla Bitkileri Bölümü, Tekirdağ \\ *Sorumlu yazar e-posta (Corresponding author; e-mail): irfan.ozturk@tarim.gov.tr \\ Geliș Tarihi (Received): 29.07.2017～Kabul Tarihi (Accepted): 20.08.2017
}

\begin{abstract}
Öz
Ekmeklik buğdayda kalite, genetik ve çevre koșullarından etkilenmekte olup çevre koșullarına bağı olarak kalite değerleri değișmektedir. Araștırmada farklı bitki gelișme dönemlerindeki kuraklığın bazı kalite karakterlerine etkileri incelenmiștir. Araștırma 15 genotip ile tesadüf bloklarında bölünmüș parseller deneme desenine göre üç tekrarlamalı olarak Edirne'de 2009 ve 2010 vejetasyon yıllarında yürütülmüștür. Denemede ana parselde kuraklık uygulamaları, alt parsellerde genotipler yer almıștır. Ana parsellerde sapa kalkma döneminden (GS31) fizyolojik olgunluk dönemine (GS94) kadar farklı dönemlerde kuraklık stresi uygulanmıștır. Tane verimi, bin tane ağırlığı, hektolitre ağırlı̆ı, ham protein oranı, tane sertliği, glüten miktarı, glüten indeksi ve sedimantasyon değeri ve bu karakterler arasındaki ikili ilișkiler incelenmiștir. Araștırma sonucunda en fazla protein oranı (\%12.5), tane sertliği (55.4) ve glüten miktarı (\%33.7) bașaklanma döneminden itibaren fizyolojik olum dönemleri arasında kuraklık uygulamalarında belirlenmiștir. En yüksek sedimantasyon değeri kontrol uygulamasında ölçülmüștür. En yüksek glüten indeksi (\%85.7), bin tane ağırlığı $(40.9 \mathrm{~g})$ ve hektolitre ağırlığı $(81.2 \mathrm{~kg} / \mathrm{hl})$ kuraklık stresi uygulanmayan koșullarda elde edilmiștir. Araștırmada incelenen kalite özelliklerine göre Aldane en yüksek kaliteye sahip çeșit olarak belirlenmiștir. Farklı dönemlerdeki kuraklık uygulamaları genotiplerde kalite özelliklerini farklı oranlarda etkilemiștir. Araștırma sonucuna göre buğdayda sapa kalkma döneminden bașaklanma dönemine kadar kuraklık stresinin olmadığı ve tane dolum süresinde toprak neminin kısmen azaldığı koșullarda ekmeklik buğdayda kalite değerlerinde artma olduğu görülmüștür.
\end{abstract}

Anahtar Kelimeler: Ekmeklik buğday, kuraklık uygulamaları, verim, kalite

\section{Drought Effect in Different Level of Plant Development Stage on Quality Characters in Bread Wheat (Triticum aestivum L) Genotypes}

\section{Abstract}

Quality in bread wheat is affected by genetic and environmental factors and quality values change depending on environmental conditions. The effects of drought stress on some quality characteristics of different plant development stages were investigated. This research was conducted with 15 genotypes and in completely randomized blocks design in split plot with three replications in Edirne in 2009 and 2010. The water stresses were imposed from shooting (GS31) up to end of during grain filling stages (GS94) of crop growth and development. Grain yield, 1000-grain weight, test weight, protein, gluten, gluten index, grain hardness and sedimentation values were investigated. According to the results, highest protein (12.5\%), grain hardness (55.4) and gluten value (33.7\%) was obtained under drought stress condition, applied from stem elongation up to physiological maturating stage. The highest sedimentation was recorded under nontreatment condition. The highest gluten index (85.7\%), 1000-kernel weight $(40.9 \mathrm{~g})$ and test weight $(81.2$ $\mathrm{kg}$ ) were obtained under non-stress condition. Result of the study indicated that Aldane has highest quality amongst investigated genotypes and based on investigated quality parameters. There wasn't any recorded drought stress from shooting up to heading stage while partially reduced soil water content during grain filling period caused an increase in quality characteristics of genotypes.

Keywords: Bread wheat, drought application, yield, quality 


\section{Giriș}

$\mathrm{T}$ rakya Bölgesi'nin yıllık ortalama yağıșı tahı üretimi için yeterli olmakla birlikte bazı yılve aylarda özellikle tane dolum döneminde yağıș miktar ve dağılıșının yetersiz ve düzensiz olması özellikle üretimde kalitenin düșmesine, sıcaklık değerlerindeki düzensizlik de kalite düșüklüğüne neden olmaktadır (Öztürk ve ark. 2016). Buğdayda tane dolum dönemindeki yüksek sıcaklık, tane verim ve kalitesini etkileyen önemli çevre faktörlerinden biridir. Çiçeklenme sonrası yüksek sıcaklık tane dolum süresini azaltır (Wardlaw and Moncur 1995; Veisz et al. 2008). Genotiplerde değișen koșullara uyum ve adaptasyon kabiliyetinin artırılması, verim ve kalite özelliğinin iyileștirilmesi, kuraklık, soğuk ve hastalıklara dayanıklıı̆ının arttıııması farklı ıslah yöntemleri ile mümkün olmaktadır (Kalaycı ve ark. 1998). Trakya Bölgesinde karșılașılan önemli sorunların bașında ekmeklik buğdayda kalite sorunu gelmektedir. Bin tane ağırlı̆̆ı, hektolitre ağırlığı, protein oranı, tane sertliği, gluten miktarı ve sedimantasyon değeri gibi kalite özelliklerinin yağıș ve sıcaklık gibi bazı iklim koșulları ile çok fazla ilișkili olduğu bilinmektedir. Protein miktarı da aynı çeșit için bölgeler arasında farklılıklar görülebilmektedir. Bunun en önemli nedeni değișen iklim koșullarıdır. Protein kalitesi kalıtım etkisi altında olan bir kriter olup, protein miktarına bağlı olarak her buğday çeșidinin de farklı performans gösterdiği bilinmektedir (Atlı 1999). Buğdayda protein, çevre koșullarına bağlı olarak \%6'dan \%25'e kadar değișebilmektedir. Protein oranında genetik yapıdan kaynaklanan varyasyon, yetiștirme koșullarındaki farklııktan daha azdır. Tane verimi ile tanedeki protein miktarı arasında negatif ilișki bulunmaktadır. Buğdayda protein oranı öncelikle iklim koșulları ve azotlu gübre uygulaması ile belirlenmekte, protein kalitesi daha çok genetik yapı tarafından kontrol edilmektedir (Blackman and Payne 1987). Protein oranı, tane dolum döneminin erken veya ileri așamasında yașanan yüksek sıcaklığa bağlıdır (Hurkman et al. 2009). Tozlanmadan sonra sıcaklık stresine maruz kalan tanelerin protein içeriğinin sıcaklık stresine göre artıș gösterdiği belirlenmiștir (Balla and Veisz 2007). Tanede protein oranı SDS sedimantasyona göre çevre koșullarından daha fazla etkilenmektedir (Pena, 2008). Nișasta tanenin kuru ağırığının \%65'ten fazlasını olușturmakta olup nișasta dolum süresindeki azalma verim düșüklüğüne neden olmaktadır (Barnabas et al. 2008; Rakszegi et al. 2006; Yan et al. 2008).

Tane sertliği buğdayın kalitesini belirleyen, genetik yapıya bağlı olmakla birlikte yetiștirme koșullarından da etkilenen önemli bir fiziksel karakterdir. Genel olarak, sert tanelerin yüksek glüten kalitesi ve protein oranına bağlı olarak ekmeklik kalitesi bakımından iyi sonuçlar verdiği kabul edilir. Bin tane ağırlığı sert buğdaylarda daha yüksek olup çeșit, iklim koșulları ve toprak özelliklerinden de etkilenmektedir (Köksel ve ark. 2000). Buğdayda tane, çiçeklenme öncesi dönemde belirlenmesine rağmen ağırığı çiçeklenme sonrası tane, dolum dönemindeki koșullara bağlıdır. Bu dönemdeki toprak ve bitkide su azlığı tane iriliğinin ve dolayısı ile bin tane ağırlığının düșmesine neden olmaktadır (Innes and Blackwell 1981). Su stresi uygulaması sulama yapılan uygulamalara göre hem sert hem de yumușak taneli buğdaylarda gluten proteininde artıșa neden olmaktadır. Ayrıca, kuraklık stresi SDS sedimantasyon değerinin artıșına katkıda bulunmaktadır (Pierre et al. 2007). Trakya Bölgesinde tahıl üretiminde özellikle tane dolum dönemindeki yağıșın düzensizliği, toprak yapısına da bağlı olarak üretimde kalite düșüklüğüne neden olmaktadır. Bölgede özellikle son ylllarda hasat öncesi ve hasat süresince düșen yağıșlar, yağıșın miktarı ve süresine, çeșitlerin genotipik yapısına da bağı olmak üzere çeșitlerde ekmeklik kalite değerlerini olumsuz yönde etkilemektedir. Bu araștırmada bitkilerin farklı gelișme dönemlerinde kuraklık uygulanarak farklı özelliklere sahip ekmeklik buğday genotiplerinde kalite özelliklerine etkisi incelenmiștir. Aynı zamanda, farklı bitki gelișme dönemlerindeki kuraklığın kalite değerlerine etkisi ve ilișkileri de araștırılmıștır.

\section{Materyal ve Yöntem}

Çalıșma Edirne lokasyonunda 20082009 ve 2009-2010 yıllarında 2 yıl süreyle yürütülmüștür. Denemede toplam 15 ekmeklik buğday genotipi tesadüf bloklarında 
bölünmüș parseller deneme desenine göre üç tekrarlamalı olarak ekilmiștir. Denemede beș ana parsel yer almıș olup, ana parselleri kuraklık uygulamaları, alt parselleri çeșitler olușturmuștur. Deneme altı sıralı ve sıra arası $17 \mathrm{~cm}$ ve $6 \mathrm{~m}^{2}$ olan parsellere metrekareye 500 tane tohum düșecek șekilde deneme ekim makinesi ile ekilmiștir.

Kuraklık uygulanacak parsellere portatif seralar kurulmuștur. Bu seraların üzeri yağmurun yağacağı dönemlerde yağmurun düșmemesi için șeffaf naylon örtülerle açılır-kapanır sistem ile kuraklık stresi olușturulmuștur. Araștırmada ana parsellerde yapilan uygulamalar; birinci uygulamada Zadoks skalasına göre GS3151 (KS1: Kuraklık Stresi-1) arasında kuraklık uygulanıp, bu dönemden sonra tane dolum dönemindegünlükbuharlașmasumiktarınagöre bir defa sulama yapılmıștır. İkinci uygulamada GS51-94 (KS2: Kuraklık stresi-2) döneminde kuraklık uygulanmıștır. KS2 uygulamasında sapa kalkma ile bașaklanma dönemleri arasında günlük buharlașma su miktarına göre bir defa sulama yapılmıștır. Üçüncü uygulamada (KS3) kuraklık stresi uygulanmamıș olup sapa kalkma, bașaklanma ve tane dolum dönemlerinde olmak üzere günlük buharlașma su miktarına göre üç defa sulama yapılmıștır. Dördüncü uygulama (KS4; Doğal uygulama, kontrol parseli) doğal parsel olup, beșinci uygulamada GS31-94 (KS5: Kuraklık stresi-5) dönemi arasında tam kuraklık uygulaması yapılmıștır. Bin tane ağırlığı otomatik tane sayıcı ile hektolitre ağırı̆ı̆ı ise otomatik hektolitre ölçüm aleti ile tespit edilmiștir. Ham protein tayini NIR yöntemine göre yapılmıștır (ICC Standart No 105 metodu). Yaș glüten miktarı ICC Standart No: 106 metoduna göre, glüten indeksi değeri ICC Standart No: $155^{\prime}$ e, sedimantasyon değeri ICC Standart No: 116 metoduna göre belirlenmiștir (Anonim 2002). Araștırmada elde edilen verilerin istatistiki değerlendirilmesinde ortalamalar en küçük önemli fark (AÖF) testi ile karșilaștırılmıștır (Gomez and Gomez 1984; Kalaycı 2005).

\section{Bulgular ve Tartıșma}

Araștırmada yıl, çeșit ve uygulamalar arasında önemli farklılık tespit edilmiștir. Araștırma sonucunda genotiplerin bin tane ağırlıkları $29.75 \mathrm{~g}$ ile $43.54 \mathrm{~g}$ arasında dağılım göstermiștir. Genotiplere göre Pehlivan çeșidi $43.54 \mathrm{~g}$ ile en yüksek bin tane ağırlığına sahip olurken, bunu $42.70 \mathrm{~g}$ ile BBVD7 hattı ve 42.14 $\mathrm{g}$ ile Aldane çeșidi takip etmiștir. Araștırmada $29.75 \mathrm{~g}$ ile en düșük bin tane ağırlığı en geç olgunlașan hat olan BBVD21-07'de ölçülmüștür.

Araștırmada beklenildiği gibi, sulama koșullarının tane iriliğini artırması nedeniyle 40.85 $\mathrm{g}$ ile en iri tane kuraklık stresi uygulanmayan KS3 ana parselinde, en düșük tane ağırlı̆ı̆ ise $34.59 \mathrm{~g}$ ile tam kuraklığın uygulandığı GS31-94 döneminde ölçülmüștür. GS31-51 dönemindeki kuraklık uygulamasında (KS1) $38.50 \mathrm{~g}$ olan tane ağırlığı geç dönem kuraklık uygulamasında (KS2) $35.71 \mathrm{~g}$ olarak tespit edilmiștir. Bu sonuçlar tane ağırlığı için GS51-94 dönemindeki yağıșın önemini ortaya koymuștur. Araștırmada yapılan değerlendirmede bin tane ağırlığı yüksek olan genotiplerin tane verimlerinde de artıș olduğu tespit edilmiștir (Çizelge 1 ve 2). Genotip ve çevrenin farklı oranlarda etkilediği hektolitre ağırlığına göre genotiplerde $83.19 \mathrm{~kg} / \mathrm{hl}$ ile en fazla miktar Selimiye çeșidinde belirlenmiș olup bütün uygulamalarda da en yüksek hektolitre ağırlığının bu çeșitte ölçülmesi, hektolitre ağırlığı açısından tane yapısının genotipik yapıya da bağlı olduğunu göstermiștir. En az hektolitre ağırlığı ise 73.56 kg ile BBVD21-07' de ölçülürken bu hattın çok geç olgunlașması nedeniyle hektolitre ağırlığı açısından geç olgunlașan genotiplerin bölge için uygun olmadığı sonucuna varılmıștır. Kuraklık uygulamalarına göre yapılan değerlendirmede GS51-94 döneminde toprakta yeterli nem olması tane iriliğini ve ağırlığını olumlu yönde etkilemiș ve dolayısı ile en yüksek hektolitre ağırlıkları bu dönemde kuraklık uygulanmayan parsellerde belirlenmiștir. Kuraklık uygulamalarına göre hektolitre ağırlıkları $77.59 \mathrm{~kg} / \mathrm{hl}$ ile $81.18 \mathrm{~kg} /$ hl arasında değișmiștir (Çizelge 1, 2). En fazla ağırlık kuraklık stresi uygulanmayan parselde (KS3), en düșük ağırlık ise tam kuraklık uygulanan (KS5) parselde tespit edilmiștir. Araștırmada faktörlerin ortalaması $79.72 \mathrm{~kg} /$ hl olarak ölçülmüștür. Çalıșmada hektolitre ağırlığının artmasının çeșitlerde tane verimini arttırdığı görülmüștür.

Bin tane ağırlığı sert buğdaylarda daha yüksek olup çeșit, iklim koșulları ve toprak özelliklerinden de etkilenmektedir (Köksel ve 
Çizelge 1. Ekmeklik Buğday genotiplerinde farklı kuraklık uygulamalarında ortalama kalite değerleri Table 1. The average quality values under various drought stress conditions in bread wheat genotypes

\begin{tabular}{lllllllll}
\hline No & Çeșitler & \multicolumn{1}{c}{ BTA } & \multicolumn{1}{c}{ HLA } & \multicolumn{1}{c}{ PRT } & \multicolumn{1}{c}{ TSR } & SED & GLT & IND \\
\hline 1 & Kate A-1 & $34.49 \mathrm{~g}$ & $81.20 \mathrm{~cd}$ & $11.43 \mathrm{fgh}$ & $55.3 \mathrm{~d}$ & $41.23 \mathrm{~d}$ & $33.83 \mathrm{~cd}$ & $72.88 \mathrm{~d}$ \\
2 & Gelibolu & $37.67 \mathrm{e}$ & $80.85 \mathrm{de}$ & $11.11 \mathrm{~h}$ & $47.0 \mathrm{j}$ & $41.30 \mathrm{~d}$ & $24.61 \mathrm{I}$ & $95.34 \mathrm{a}$ \\
3 & Pehlivan & $43.54 \mathrm{a}$ & $81.63 \mathrm{~b}$ & $11.73 \mathrm{~d}-\mathrm{g}$ & $53.5 \mathrm{f}$ & $41.63 \mathrm{~d}$ & $34.70 \mathrm{bc}$ & $72.55 \mathrm{~d}$ \\
4 & Tekirdağ & $38.82 \mathrm{~d}$ & $78.91 \mathrm{~g}$ & $11.91 \mathrm{cde}$ & $53.7 \mathrm{f}$ & $45.33 \mathrm{c}$ & $32.76 \mathrm{de}$ & $83.28 \mathrm{c}$ \\
5 & Selimiye & $41.47 \mathrm{c}$ & $83.19 \mathrm{a}$ & $11.57 \mathrm{efg}$ & $55.1 \mathrm{~d}$ & $45.10 \mathrm{c}$ & $31.91 \mathrm{e}$ & $90.26 \mathrm{~b}$ \\
6 & Aldane & $42.14 \mathrm{bc}$ & $81.34 \mathrm{bc}$ & $12.78 \mathrm{~b}$ & $55.2 \mathrm{~d}$ & $56.03 \mathrm{a}$ & $34.36 \mathrm{bc}$ & $94.05 \mathrm{a}$ \\
7 & Flamura-85 & $37.28 \mathrm{e}$ & $80.65 \mathrm{e}$ & $12.05 \mathrm{~cd}$ & $53.3 \mathrm{fg}$ & $47.77 \mathrm{~b}$ & $30.40 \mathrm{fg}$ & $94.40 \mathrm{a}$ \\
8 & Golia & $31.90 \mathrm{~h}$ & $79.86 \mathrm{f}$ & $11.95 \mathrm{cde}$ & $57.8 \mathrm{~b}$ & $35.03 \mathrm{~g}$ & $28.74 \mathrm{~h}$ & $94.16 \mathrm{a}$ \\
9 & BBVD7 & $42.70 \mathrm{ab}$ & $78.89 \mathrm{~g}$ & $12.32 \mathrm{c}$ & $51.1 \mathrm{~h}$ & $37.23 \mathrm{ef}$ & $34.60 \mathrm{bc}$ & $64.82 \mathrm{f}$ \\
10 & Bereket & $37.91 \mathrm{e}$ & $80.63 \mathrm{e}$ & $11.41 \mathrm{gh}$ & $52.8 \mathrm{~g}$ & $44.73 \mathrm{c}$ & $28.67 \mathrm{~h}$ & $94.52 \mathrm{a}$ \\
11 & ÖVD26-07 & $35.61 \mathrm{f}$ & $81.21 \mathrm{~cd}$ & $11.83 \mathrm{def}$ & $58.6 \mathrm{a}$ & $36.63 \mathrm{f}$ & $31.56 \mathrm{ef}$ & $88.21 \mathrm{~b}$ \\
12 & ÖVD2/21-07 & $37.23 \mathrm{e}$ & $76.95 \mathrm{~h}$ & $11.49 \mathrm{fgh}$ & $50.4 \mathrm{I}$ & $47.80 \mathrm{~b}$ & $28.47 \mathrm{~h}$ & $93.89 \mathrm{a}$ \\
13 & ÖVD2/27-07 & $34.56 \mathrm{~g}$ & $79.87 \mathrm{f}$ & $11.42 \mathrm{fgh}$ & $55.7 \mathrm{~d}$ & $36.90 \mathrm{f}$ & $35.20 \mathrm{~b}$ & $60.76 \mathrm{~g}$ \\
14 & EBVD24-07 & $31.21 \mathrm{~h}$ & $77.08 \mathrm{~h}$ & $11.70 \mathrm{~d}-\mathrm{g}$ & $54.3 \mathrm{e}$ & $38.67 \mathrm{e}$ & $30.21 \mathrm{~g}$ & $83.63 \mathrm{c}$ \\
15 & BBVD21-07 & $29.75 \mathrm{I}$ & $73.56 \mathrm{I}$ & $13.32 \mathrm{a}$ & $57.0 \mathrm{c}$ & $34.27 \mathrm{~g}$ & $37.01 \mathrm{a}$ & $68.88 \mathrm{e}$ \\
\hline Ortalama & 37.08 & 79.72 & 11.86 & 54.1 & 41.98 & 31.8 & 83.44 \\
A. Ö. F. (0.05) & 0.88 & 0.40 & 0.41 & 0.58 & 1.59 & 1.29 & 2.32 \\
$\mathrm{~F}$ & & $* *$ & $* *$ & $* *$ & $* *$ & $* *$ & $* *$ & $* *$ \\
\hline
\end{tabular}

Not: **: P<0.01; *: P<0.05; BTA: Bin tane ağırlığı (g), HLA: Hektolitre ağırığı (kg), PRT: Protein (\%), TSR (NIR): Tane sertliği, SED: Sedimantasyon (Zel) (ml), GLT: Gluten (\%), IND: Gluten indeksi (\%)

Note: **: P<0.01, *: P<0.05, BTA: Thousand kernel weight (g), HLA: Test weight (kg), PRT: Protein (\%), TSR: Hardness,

SED: sedimentation (ml), GLT: Gluten (\%), IND: Gluten index

ark. 2000). Buğdayda tane ağırlığı çiçeklenme öncesi dönemde belirlenmesine rağmen ağırlı̆ı̆ derecesi çiçeklenme sonrası tane dolum dönemindeki koșullara bağlıdır. Bu dönemdeki toprak ve bitkide su azlığı tane iriliğinin ve dolayısı ile bin tane ağırlığının düșmesine neden olduğu (Innes and Blackwell 1981) araștırma sonucunda da görülmüștür.
Ekmeklik buğdayda genotip ve çevre koșullarına göre değișkenlik gösteren protein oranı genotiplerde \%11.11 ile \%13.32 arasında dağılım göstermiștir. Araștırmada en yüksek protein oranı \%13.32 ile BBVD21-07 hattı ve \%12.78 ile Aldane çeșidinde belirlenmiștir. Farklı bitki gelișme dönemlerinde uygulanan kuraklık seviyelerine göre protein oranı \%11.31

Çizelge 2. Farklı kuraklık stresinde tespit edilen ortalama kalite parametreleri

Table 2. Average quality parameters determined in different drought stress conditions

\begin{tabular}{lllllllll}
\hline Uygulama & VRM & BTA & HLA & PRT & TSR & SED & GLT & IND \\
\hline KS1 & $549.9 \mathrm{~d}$ & $38.50 \mathrm{~b}$ & $80.81 \mathrm{~b}$ & $11.69 \mathrm{c}$ & $54.0 \mathrm{a}$ & $43.07 \mathrm{~b}$ & $31.93 \mathrm{c}$ & $81.92 \mathrm{c}$ \\
KS2 & $563.9 \mathrm{c}$ & $35.71 \mathrm{c}$ & $79.16 \mathrm{~d}$ & $12.54 \mathrm{a}$ & $55.4 \mathrm{a}$ & $43.02 \mathrm{~b}$ & $33.68 \mathrm{a}$ & $82.61 \mathrm{bc}$ \\
KS3 & $763.8 \mathrm{a}$ & $40.85 \mathrm{a}$ & $81.18 \mathrm{a}$ & $11.63 \mathrm{c}$ & $53.9 \mathrm{~b}$ & $40.93 \mathrm{c}$ & $30.87 \mathrm{~d}$ & $85.74 \mathrm{a}$ \\
KS4 & $579.7 \mathrm{~b}$ & $35.78 \mathrm{c}$ & $79.87 \mathrm{c}$ & $12.18 \mathrm{~b}$ & $53.2 \mathrm{c}$ & $43.83 \mathrm{a}$ & $32.70 \mathrm{~b}$ & $83.59 \mathrm{~b}$ \\
KS5 & $457.8 \mathrm{e}$ & $34.59 \mathrm{~d}$ & $77.59 \mathrm{e}$ & $11.31 \mathrm{~d}$ & $53.7 \mathrm{~b}$ & $39.03 \mathrm{~d}$ & $29.83 \mathrm{e}$ & $83.37 \mathrm{~b}$ \\
\hline Ortalama & 583.0 & 37.08 & 79.72 & 11.86 & 54.1 & 41.98 & 31.80 & 83.44 \\
A. Ö. F (0.05) & 12.69 & 0.38 & 0.16 & 0.19 & 0.36 & 0.72 & 0.65 & 1.14 \\
F & $* *$ & $* *$ & $* *$ & $* *$ & $* *$ & $* *$ & $* *$ & $* *$ \\
\hline
\end{tabular}

Not: **: P<0.01; *: P<0.05; VRM: Verim (kg/da), BTA: Bin tane ağırlığı (g), HLA: Hektolitre ağırığı (kg), PRT: Protein (\%), TSR (NIR): Tane sertliği, SED: Sedimantasyon (Zel) (ml), GLT: Gluten (\%), IND: Gluten indeksi (\%), KS: Kuraklık stresi

Note: **: P<0.01, *: P<0.05, VRM: Yield (kg/da), BTA: Thousand kernel weight (g), HLA: Test weight (kg), PRT: Protein (\%), TSR: Hardness, SED: sedimentation (ml), GLT: Gluten (\%), IND: Gluten indeksi, KS: Drought stress 
ile \%12.54 arasında dağılım göstermiștir. En yüksek protein oranı KS2 döneminde tespit edilmiștir. Bu sonuçlara göre Trakya Bölgesinde ürünlerde düșük proteinin tane dolum süresindeki yüksek yağıștan kaynaklandığı, yüksek proteinli ürün elde edilebilmesi için özellikle tane dolum döneminde fazla yağıșın olmaması gerektiği sonucuna varılmıștır. Araștırmada en düșük protein oranı $\% 11.31$ ile tam kuraklık uygulanan parselde belirlenmiș olup özellikle yapılan azotlu gübrelemeden de yeterince yararlanamadığı yorumu yapılmıștır (Çizelge 1 ve 2).

Protein oranı ile yüksek oranda ilișkili olan tane sertliğine göre genotip ve uygulamalar arasında farkllık olduğu tespit edilmiștir. Araștırmada en yumușak tanelerin her iki yıl ve beș uygulamada da Gelibolu çeșidinde tespit edilmesi tane sertliğinin genotipik yapıya da bağlı olduğunu göstermiștir. Kuraklık uygulamalarına göre yapılan değerlendirmede tane sertliği 53.2 ile 55.4 arasında değișmiștir. Araștırmada her iki yılda da en yumușak taneler doğal uygulamada elde edilirken, en sert taneler erken dönem kuraklık uygulanan parsellerde tespit edilmiștir (Çizelge 1 ve 2). Bu sonuca göre bașaklanma dönemine kadar bitkilerin kuraklık stresine maruz kalmaması ve takibinde tane dolum dönemindeki kısmen kurak koșullar veya yağıșın fazla olmaması daha sert yapıda tanelerin olușmasını sağlamıștır. Bu sonuçlar, Trakya Bölgesinde ekmeklik buğdaylarda bazı yıllarda düșük kaliteli ürün elde edilmesine, tane dolum dönemi ve hasat dönemindeki yağıșın etkisinin olduğunu göstermiștir.

Araștırmada çeșitlerde tane sertliğinin yüksek olduğu koșullarda protein oranı ile gluten miktarının da yükseldiği görülmüștür. Ekmeklik buğdayda tane sertliği bazı araștırmacılar tarafından da ele alınmıștır. Kalite karakterlerindeki değișikliğe çevrenin etkisi genetik faktörün etkisinden daha fazla olduğu, tane sertliğine genotipin etkisi ile genotip $\mathrm{x}$ çevrenin birlikte etkisinin daha fazla olduğu (Peterson et al. 1992) bu çalıșma sonucunda da görülmüștür.

Araștırmada, diğer kalite özelliklerine göre yüksek değerlere sahip olduğu tespit edilen Aldane çeșidinde $56.03 \mathrm{ml}$ ile en yüksek sedimantasyon değeri elde edilmiștir. Ayrıca, bu çeșitte bütün uygulamalarda da yüksek sedimantasyon değerinin tespit edilmesi, sedimantasyon değerinin çevre ve genotipik yapıdan etkilendiğini göstermiștir. Kuraklık uygulamalarına göre yapılan değerlendirmede $43.83 \mathrm{ml}$ ile en fazla sedimantasyon değeri doğal parsellerde ölçülürken, GS31-51 ve GS51-94 dönemlerinde de yüksek sedimantasyon değeri ölçümü yapılmıștır. Çalıșmada, tam kuraklık uygulanan parsellerde $39.03 \mathrm{ml}$ ile en düșük sedimantasyon değeri ölçülmüștür (Çizelge 1 ve 2). Bu durum, sedimantasyonun değerinin genotipik yapıya bağlı olduğu gibi çevre koșullarından da önemli oranda etkilendiğini göstermiștir.

Araștırmada genotipler arasında en yüksek glüten miktarı $\% 37.01$ ile BBVD2107, \%35.20 ile ÖVD2/27-07 ve \%34.70 ile Pehlivan'da ölçülmüștür. En yüksek gluten oranı protein ve tane sertliğinde olduğu gibi GS51-94 döneminde kuraklık uygulamasında tespit edilmiștir. Kuraklık uygulamalarına göre tane dolum dönemi (KS2) kuraklıkta \%33.68 ile en yüksek glüten değeri tespit edilmiștir. Bașaklanma dönemine kadar kuraklık stresinin olmaması ve tane dolum döneminde ise toprak neminde kısmen azalmanın olduğu koșulların, ekmeklik buğdayda gluten miktarını arttırdığı tespit edilmiștir. Kuraklık stresi uygulanmayan koșullar ile tam kuraklık uygulamaları gluten miktarını düșürmüștür. Bu sonuçlar, fazla yağıșlı koșullarla birlikte sapa kalkma döneminden tane dolum dönemine kadar kuraklık stresine maruz kalınmasının, besin elementleri alımını da engelleyeceği için genotiplerdeki gluten miktarını düșürdüğü sonucuna ulașılmıștır. Araștırmada, genotiplerde en yüksek gluten indeksi değeri \%95.34 ile Gelibolu çeșidinde belirlenmiștir. Ayrıca Bereket, Golia, Flamura-85, Aldane ve ÖVD2/21 genotiplerinin de \%90'nın üzerinde gluten indeksine sahip olduğu saptanmıștır. Uygulama konularına göre yapılan değerlendirmede kuraklık uygulamaları glüten indeksini düșürdüğü tespit edilmiștir. Bu sonuçlar gluten indeksinde genotip ve çevrenin birlikte etkisinin önemli olduğunu göstermiștir.

Kuraklık uygulanan ana parsellere göre yapılan değerlendirmede tane verimi ile bin tane ağırlığı $\left(R^{2}=0.736\right)$, hektolitre ağırlı̆ı $\left(R^{2}=0.624\right)$ ve gluten indeksi $\left(R^{2}=0.580\right)$ arasında yüksek 


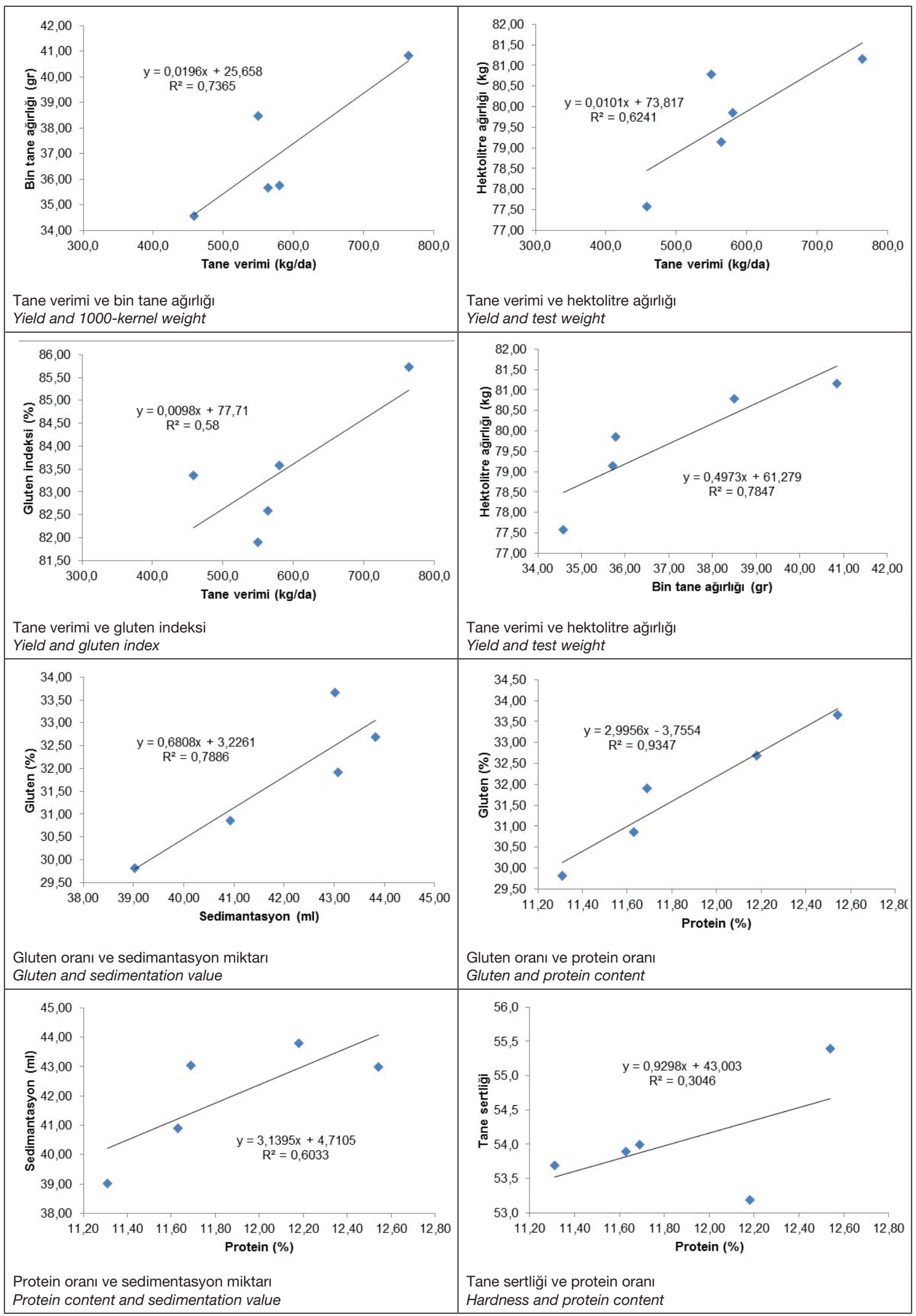

Șekil 1. Farklı seviyede kuraklık uygulamasında kalite karakterleri arasındaki ikili ilișkiler Figure 1. The relationship among quality characters under different drought stress conditions 
oranda olumlu ilișki belirlenmiștir. Ayrıca, hektolitre ağırlığı ile bin tane ağırlığı, gluten oranı ile protein ve sedimantasyon değeri, protein oranı ile sedimantasyon değeri arasında olumlu ilișki saptanmıștır (Șekil 1).

Araștırmada incelenen karakterler arasında ve beș farklı kuraklık seviyesine göre korelasyon değerleri belirlenmiștir (Çizelge 3). Sapa kalkma döneminden bașaklanma dönemine kadar (GS31-51) erken dönem kuraklık uygulamasında tane verimi ile protein oranı arasında negatif ilișkinin olduğu, gluten indeksi ile gluten miktarı arasında da yüksek oranda negatif ilișkinin olduğu belirlenmiștir. Araștırmada, hektolitre ağırlığı fazla olan genotiplerde tane verimi artıșı olduğu, daha sert taneli çeșitlerde daha yüksek protein oranına ulașıldığı belirlenmiștir. Protein oranı ile gluten miktarı arasında yüksek oranda pozitif ilișki saptanmıștır. Ayrıca, hektolitre ağırlığı ile sedimantasyon değeri ve gluten indeksi arasında olumlu ilișki saptanırken, protein oranı ile olumsuz ilișki tespit edilmiștir. Araștırmada tane verimi ile hektolitre ağırığı $(r=0.360)$ arasında olumlu ve çok önemli, bin tane ağırlığı ( $r=0.248)$ ile olumlu ve önemli, protein oranı $(r=-0.341)$ ile olumsuz ve çok önemli ilișki tespit edilmiștir.

Hektolitre ağırlığı ile bin tane ağırlığı $(r=0.420)$, sedimantasyon değeri $(r=0.380)$ ve gluten indeksi arasında olumlu ve çok önemli, protein oranı $(r=-0.398)$ ve gluten miktarı $(r=-0.331)$ arasında olumsuz ve çok önemli ilișki saptanmıștır. Protein oranı ile tane sertliği $(r=0.486)$, gluten miktarı $(r=0.770)$ ve tane sertliği ile gluten arasında $(r=0.622)$ olumlu ve çok önemli ilișkinin olduğu belirlenmiștir.

Araștırmada bașaklanma döneminden fizyolojik olgunlașma dönemine kadar uygulanan (GS51-94) kuraklıkta; tane verimi ile protein oranı arasında negatif ilișkinin olduğu, yine glüten indeksi ile gluten arasında da yüksek oranda negatif ilișkinin olduğu gluten miktarı artıșının gluten indeksini düșürdüğü belirlenmiștir. Araștırmada, hektolitre ağırlığı fazla olan genotiplerde tane veriminin de yüksek olduğu, daha sert taneli çeșitlerde daha yüksek protein oranına ulașılmıștır. Protein oranı ile gluten miktarı arasında yüksek oranda pozitif ilișki bütün uygulamalarda görülmüștür. Ayrıca, hektolitre ağırlığı ile sedimantasyon değeri ve gluten indeksi arasında olumlu ilișki saptanırken, protein oranı ile olumsuz ilișki tespit edilmiștir. Geç dönem kuraklıkta (GS51-94); tane verimi ile hektolitre ağırlığı $(r=0.490)$ ve bin tane ağırlığı arasında $(r=0.585)$ olumlu ve çok önemli, protein oranı $(r=-0.590)$, sedimantasyon değeri $(r=-0.303)$ ve gluten miktarı $(r=-0.336)$ arasında olumsuz ve çok önemli ilișki tespit edilmiștir. Protein oranı ile sedimantasyon değeri $(r=0.450)$ ve gluten miktarı $(r=0.668)$ arasında olumlu ve çok önemli ilișki saptanmıștır. Tane sertliği ile gluten miktarı ( $r=0.346)$ arasında olumlu ve çok önemli, sedimantasyon değeri $(r=-0.553)$ ve gluten indeksi ( $r=-0.444)$ arasında olumsuz ve çok önemli ilișki tespit edilmiștir.

Araștırmada tam kuraklığın uygulandığı GS31-94 döneminde tane verimi ile hektolitre ağırlığı ( $r=0.683$ ) ve bin tane ağırlığı arasında $(r=0.499)$ olumlu ve çok önemli, protein oranı $(r=-0.415)$ ile olumsuz ve çok önemli ilișki tespit edilmiștir. Protein oranı ile sedimantasyon değeri $(r=0.295)$ ve gluten miktarı $(r=0.638)$ arasında olumlu ve çok önemli ilișki, hektolitre ağırlığı ( $r=-0.490)$ ve bin tane ağırlığı arasında ( $r=-0.355)$ olumsuz ve çok önemli ilișki saptanmıștır. Bu sonuçlara göre, tam kuraklığın uygulandığı koșullarda hektolitre ağırlığı ve bin tane ağırlığının artıșı tane verimini önemli oranda artırmıștır. Hektolitre ağırlığındaki artıș protein oranını düșürmüștür.

Araștırmadakuraklıkstresininuygulanmadığı sulama destekli koșullarda hektolitre ağırlığı ve bin tane ağırlığı artıșı genotiplerde tane verimini artırmıș olup, protein oranı, tane sertliği ve gluten miktarındaki yükselme ile de verim arasında olumsuz ilișki belirlenmiștir. Protein oranındaki artıșa paralel olarak sedimantasyon değeri ve gluten miktarında da artıș olmuștur. Sert tane yapısına sahip genotiplerde daha düșük sedimantasyon ve gluten indeksi belirlenirken, gluten miktarında artıș olduğu görülmüștür. Bütün uygulamalarda olduğu gibi gluten indeksi ile gluten miktarı arasında olumsuz, sedimantasyon değeri ile olumlu ilișki belirlenmiștir. Araștırmada, doğal koșullardaki uygulamalarda hektolitre ağırlığı ve bin tane ağırlığındaki artıș genotiplerde tane verimini de artırmıș olup, protein ve gluten miktarı ile sedimantasyon miktarının tane verimi ile negatif ilișkili olduğu görülmüștür. 
Çizelge 3. Farklı seviyede kuraklık uygulamasında kalite kriterlerindeki korelasyon katsayıları

Table 3. Correlation coefficient among quality parameters under various drought stress conditions

\begin{tabular}{|c|c|c|c|c|c|c|c|}
\hline \multicolumn{8}{|c|}{ Erken dönem kuraklık uygulamasında tane verimi ve kalite özellikleri arasındaki korelasyon } \\
\hline KS1 & VRM & HLA & BTA & PRT & TSR & SED & GLT \\
\hline HLA & $0.360^{\star *}$ & & & & & & \\
\hline BTA & $0.248^{*}$ & $0.420^{\star *}$ & & & & & \\
\hline PRT & $-0.341^{* *}$ & $-0.398^{\star *}$ & -0.090 & & & & \\
\hline TSR & -0.092 & -0.199 & $-0.219^{*}$ & $0.486^{\star \star}$ & & & \\
\hline SED & -0.091 & $0.380^{\star *}$ & $0.263^{*}$ & 0.109 & $-0.360^{\star \star}$ & & \\
\hline GLT & -0.188 & $-0.331^{\star *}$ & 0.105 & $0.770^{\star \star}$ & $0.622^{\star *}$ & -0.117 & \\
\hline IND & -0.005 & $0.410^{\star \star}$ & -0.096 & $-0.328^{\star \star}$ & $-0.429^{\star \star}$ & $0.520^{\star \star}$ & $-0.736^{\star \star}$ \\
\hline \multicolumn{8}{|c|}{ Geç dönem kuraklık uygulamasında tane verimi ve kalite özellikleri arasındaki korelasyon } \\
\hline KS2 & VRM & HLA & BTA & PRT & TSR & SED & GLT \\
\hline HLA & $0.490^{\star \star}$ & & & & & & \\
\hline BTA & $0.585^{\star \star}$ & $0.560^{\star \star}$ & & & & & \\
\hline PRT & $-0.590^{\star *}$ & $-0.359^{* *}$ & $-0.324^{* *}$ & & & & \\
\hline TSR & 0.054 & -0.045 & -0.010 & 0.024 & & & \\
\hline SED & $-0.303^{\star *}$ & 0.174 & -0.115 & $0.450^{\star *}$ & $-0.553^{\star *}$ & & \\
\hline GLT & $-0.336^{\star \star}$ & $-0.217^{\star}$ & -0.070 & $0.668^{\star \star}$ & $0.346^{\star \star}$ & 0.057 & \\
\hline IND & -0.054 & $0.300^{* *}$ & -0.032 & -0.053 & $-0.444^{\star *}$ & $0.560^{* *}$ & $-0.612^{* *}$ \\
\hline \multicolumn{8}{|c|}{ Kuraklık stresi olmayan (KS3) koșullarda verim ve kalite özellikleri arasındaki korelasyon } \\
\hline KS3 & VRM & HLA & BTA & PRT & TSR & SED & GLT \\
\hline HLA & $0.573^{\star \star}$ & & & & & & \\
\hline BTA & $0.380^{\star \star}$ & $0.480^{\star \star}$ & & & & & \\
\hline PRT & $-0.374^{\star \star}$ & -0.174 & $-0.299^{* *}$ & & & & \\
\hline TSR & $-0.316^{\star \star}$ & -0.202 & -0.196 & 0.073 & & & \\
\hline SED & 0.145 & $0.418^{\star *}$ & 0.124 & $0.490^{\star \star}$ & $-0.434^{\star *}$ & & \\
\hline GLT & $-0.342^{\star \star}$ & $-0.215^{\star}$ & 0.002 & $0.559^{\star \star}$ & $0.459^{\star \star}$ & 0.062 & \\
\hline IND & 0.196 & $0.409^{* *}$ & -0.036 & 0.114 & $-0.418^{* *}$ & $0.568^{* *}$ & $-0.575^{\star *}$ \\
\hline \multicolumn{8}{|c|}{ Doğal koșullarda (KS4) yürütülen uygulamada verim ve kalite özellikleri arasındaki korelasyon } \\
\hline KS4 & VRM & HLA & BTA & PRT & TSR & SED & GLT \\
\hline HLA & $0.548^{\star \star}$ & & & & & & \\
\hline BTA & $0.499^{\star *}$ & $0.542^{* *}$ & & & & & \\
\hline PRT & $-0.599^{\star \star}$ & $-0.510^{\star \star}$ & $-0.230^{\star}$ & & & & \\
\hline TSR & -0.066 & -0.023 & -0.072 & $0.296^{\star *}$ & & & \\
\hline SED & $-0.312^{\star \star}$ & 0.167 & -0.027 & $0.265^{*}$ & $-0.374^{\star \star}$ & & \\
\hline GLT & $-0.284^{\star \star}$ & $-0.357^{\star \star}$ & 0.018 & $0.671^{\star \star}$ & $0.564^{\star \star}$ & -0.166 & \\
\hline IND & -0.087 & $0.296^{\star \star}$ & -0.113 & $-0.216^{*}$ & $-0.305^{\star *}$ & $0.529^{* *}$ & $-0.718^{\star *}$ \\
\hline \multicolumn{8}{|c|}{ Tam kuraklık uygulamasında (KS5) tane verimi ile kalite özellikleri arasındaki korelasyon } \\
\hline KS5 & VRM & HLA & BTA & PRT & TSR & SED & GLT \\
\hline HLA & $0.683^{\star \star}$ & & & & & & \\
\hline BTA & $0.548^{\star \star}$ & $0.742^{\star *}$ & & & & & \\
\hline PRT & $-0.415^{\star \star}$ & $-0.490^{\star *}$ & $-0.355^{\star *}$ & & & & \\
\hline TSR & 0.169 & $0.328^{\star \star}$ & 0.204 & 0.183 & & & \\
\hline SED & -0.131 & -0.096 & -0.029 & $0.295^{\star \star}$ & $-0.379^{\star *}$ & & \\
\hline GLT & -0.106 & -0.105 & 0.095 & $0.638^{\star *}$ & $0.460^{\star \star}$ & 0.016 & \\
\hline IND & -0.118 & -0.032 & -0.186 & -0.072 & -0.324 & $0.521^{\star *}$ & $-0.652^{* *}$ \\
\hline
\end{tabular}

Not: **: P<0.01; *: P<0.05; VRM: Verim (kg/da), BTA: Bin tane ağırlığı (g), HLA: Hektolitre ağılığı (kg), PRT: Protein (\%), TSR (NIR): Tane sertliği, SED: Sedimantasyon (Zel) (ml), GLT: Gluten (\%), IND: Gluten indeksi (\%), KS: Kuraklık stresi

Note: **: $P<0.01$, *: P<0.05, VRM: Yield (kg/da), BTA: Thousand kernel weight (g), HLA: Test weight (kg), PRT: Protein (\%), TSR: Hardness, SED: sedimentation (ml), GLT: Gluten (\%), IND: Gluten indeksi, KS: Drought stress

\section{Sonuç}

Farklı bitki gelișme dönemlerindeki çalıșmada, tane dolum dönemindeki sulama kuraklığın kalite kriterlerine etkisinin araștırılığı koșullarının genotiplerde kalite değerlerini 
düșürdüğü belirlenmiștir. Araștırmada bin tane ve hektolitre ağırlığı açısından önemli varyasyon olduğu genotipler arasında en yüksek bin tane ağırlığı Pehlivan çeșidinden, en fazla hektolitre ağırlığı ise Selimiye çeșidinden elde edilmiștir. Tane dolum döneminde toprakta yeterli nem olması tane iriliğini ve ağırlığını olumlu yönde etkilediğinden dolayı, en yüksek hektolitre ağırlıkları tane dolum dönemi kuraklık uygulanmayan koșullarda belirlenmiștir. Trakya Bölgesinde ekmeklik buğdayda protein değerinde yıldan yıla ve bölgelere göre değișkenlik yașanmaktadır. Araștırmada özellikle tane dolum döneminde sulama koșullarının tanedeki protein oranını azalttığı belirlenmiștir. Araștırmada beklenildiği gibi tane verimi ile ters ilișkili olmasından dolayı protein oranının yükseldiği koșullarda tane veriminde azalma olmuștur. Protein ile yüksek oranda ilișkili olan tane sertliği de tane dolum dönemindekikurakkoșullardaartıșgöstermiștir. Kuraklık uygulamalarına göre, bașaklanma dönemine kadar bitkilerin kuraklık stresine maruz kalmaması ve tane dolum döneminde nispeten kuraklık stresi uygulamalarının gluten miktarını arttırdığı saptanmıștır. Geç dönem kuraklıkta protein oranı, gluten miktarı ile tane sertliğinde artıș olmuștur. Aldane çeșidinde en yüksek sedimantasyon değeri saptanmıștır. Yapılan çalıșmada kuraklık stresinin olmadığı sulama destekli uygulama ile tam kuraklık stresinde sedimantasyon değerinin azaldığı belirlenmiștir. Doğal koșullarda en yüksek sedimantasyon değeri tespit edilmiștir. Araștırmada, ekmeklik kalite değeri en yüksek çeșidin Aldane olduğu, aynı zamanda bu çeșidin kuraklık uygulamalarından da en az etkilendiği belirlenmiștir. Bu sonuçlar, Trakya Bölgesinde ekmeklik buğdaylarda karșılașılan kalite düșüklüğünün özellikle tane dolum dönemi ve hasat döneminde yağan yağıștan kaynaklandığını göstermiștir. Bu nedenle, Trakya Bölgesinde yüksek kaliteli ürünün, çeșide göre değișmekle birlikte, tane dolum döneminde fazla yağıșın olmadığı koșullarda elde edilmesinin mümkün olacağı sonucuna varılmıștır.

\section{Kaynaklar}

Anonim, 2002. International association for cereal science and technology. ICC Standart No: 105, 106, 155, 116, 115
Anonim, 2008. Ülkesel serin iklim tahılları araștırma projesi. 2008 Yılı Araștırma Projeleri Raporu, Edirne

Atlı A., 1999. Buğday ve ürünleri kalitesi. Orta Anadolu'da Hububat Tarımının Sorunları ve Çözüm Yolları Sempozyumu, s. 498-506. Konya

Balla K., and Veisz O., 2007. Changes in the quality of cereals in response to heat and drought stress. Acta Agronomica Óvariensis, 49:451455

Barnabas B., Jager K., and Feher A., 2008. The effect of drought and heat stress on reproductive processes in cereals. Plant, Cell and Environment, 31(1):11-38 DOI: 10.1111/j.13653040.2007.01727.x

Blackman J.A., and Payne P.I., 1987. Grain quality. In: Lupton, F.G.H. Wheat breeding: its scientific basis. pp. 455-485, Chapman and Hall, New York

Elgün A., Türker S. ve Bilgiçli N., 2001. Tahıl ve ürünlerinde analitik kalite kontrolü. Selçuk Üniversitesi Ziraat Fakültesi, Gıda Mühendisliği Bölümü Yayınları:2, Konya

Gomez K.A., and Gomez A.A., 1984. Statistical procedures for agricultural research, 2nd ed. p. 641. John Wiley and Sons, Inc. New York

Hurkman W.J., Vensel W.H., Tanaka C.K., Whitehand L., and Altenbach S.B., 2009. Effect of high temperature on albumin and globulin accumulation in the endosperm proteome of the developing wheat grain. Journal of Cereal Science, 49:12-23

Innes P., and Blackwell R.D., 1981. The effect of drought on the water use and yield of two spring wheat genotypes. The Journal of Agricultural Science, Cambridge University Press, 96:603610 DOI: 10.1017/S0021859600034584

Kalayci M., Aydin M., Ozbek V., Cekic C., Ekiz H., Keser M., Altay F., Ekiz H., Yilmaz A., Kinaci E. ve Cakmak I.., 1998. Orta Anadolu koșullarında kurağa dayanıklı buğday genotiplerinin belirlenmesi ve morfolojik ve fizyolojik parametrelerin geliștirilmesi. TUBITAK PROJESI, Bahri Dağdaș Uluslararası Tarımsal Araștırma Enstitüsü

Kalaycı M., 2005. Örneklerle JUMP kullanımı ve tarımsal araștırma için varyans analiz modelleri. Anadolu Tarımsal Araștırma Enstitüsü Müdürlüğü Yayınları:21, Eskișehir

Köksel H., Sivri D., Özboy O., Bașman A. ve Karacan H.D., 2000. Tahıl Laboratuarı El Kitabı. Hacettepe Üniversitesi Mühendislik Fakültesi Yayınları:47, Ankara

Öztürk İ., Kahraman T., Avcı R., Girgin V.Ç., Așkın O.O., Așkın B., Tuna B., and Tülek A., 2016. Effect of rainfall and humidity during shooting and grain filling period on yield and quality in bread wheat. VII International Scientific Agriculture Symposium "Agrosym 2016" 6-9 October 2016, Book of Proceeding, p. 13921400. Johorina, Bosnia and Herzegovina 
Pena R.J., 2008. Improving or preserving bread making quality while enhancing grain yield in wheat. In: Reynolds M.P., Pietragalla J., Braun H.J. (Eds). International symposium on wheat yield potential: challenges to international wheat breeding. Mexico: CIMMYT; 2008. pp. 171-174

Saint Pierre C., Peterson C.J., Ross A.S., Ohm J., Verhoeven M.C., Larson M., and Hoefer B., 2007. Grain protein content and composition of winter wheat cultivars under different levels of $\mathrm{N}$ and water stress. Developments in Plant Breeding, 12: 535-542

Rakszegi M., Lang L., and Bedö Z., 2006. Importance of starch properties in quality oriented wheat breeding. Cereal Research Communications, 34: $637-640$
Veisz O., Bencze Sz., Balla K., and Vida Gy., 2008. Change in water stress resistance of cereals due to atmospheric $\mathrm{CO} 2$ enrichment. Cereal Research Communications, 36: 1095-1098

Wardlaw I.F., and Moncur L., 1995. The response of wheat to high temperature following anthesis. I. The rate and duration of kernel filling. Australian Journal of Plant Physiology, 22: 391-397

Yan S.H., Yin Y.P., Li W.Y., Li Y., Liang T.B., Wu Y.H., Geng Q.H., and Wang Z.L., 2008. Effect of high temperature after anthesis on starch formation of two wheat cultivars differing in heat tolerance. Acta Ecologica Sinica, 28: 6138-6147

Zadoks J.C., Chang T.T., and Konzak C.F., 1974. A decimal code for growth stages of cereals. Weed Res. 14: 415-421 DOI: 10.1111/j.13653180.1974.tb01084.x 